\title{
The Effect of Accessibility of Internet Financial Reporting on E- Government of Cities/Regencies in West Java
}

\author{
Arthaingan Helmina Mutiha ${ }^{1}$ \\ ${ }^{1}$ Accounting Department, Vocational Education Program, Universitas Indonesia \\ *Email: h.mutiha@ui.ac.id
}

\begin{abstract}
This study aimed at analyzing whether there is a significant and positive correlation between the ratio of the regional revenue and the size of the local government and the ratio of regional spending and income per capita of the resident of a local region with the accessibility of Internet financial reporting by using government website (e-government). This study considered all cities and regencies in West Java provided their e-government website was not under repair during observation in April 2018. The study was triggered by Law No. 14 of 2008 on Public Information, which obliges governments to disseminate public information in a way that is easily accessible by the public. This can be accomplished using e-government. The results show that there is no significant relationship between the ratio of local regional revenue and the size of local government, and the ratio of regional spending and income per capita of a local government with the accessibility of Internet financial reporting.
\end{abstract}

Keywords: Internet financial reporting, e-government, financial ratio

\section{Introduction}

Act No. 14 in 2008 regarding public disclosure states that obtaining public information is a citizen's right that must be protected. Laws and public bodies are required to apply a good information system to accurately convey public information through electronic and non-electronic media. This is also in line with the government agenda of financial reforms and regional autonomy to achieve accountability and transparency of government management. The existence of transparency is marked by the fulfillment of public information to the people through media where people can easily access it.

The development of information technology facilitates access to this information. Information technology such as the Internet allows people to exchange information quickly and easily. One of the media that can be used to disseminate information about local government activity is the official website of local governments, namely e-government. The government has issued instructions on strategies and policies on e-government through Presidential Instruction (Inpres) No. 3 of 2003, followed by the Ministry of Telecommunications and Informatics issuing Guidelines for Local Government Website Implementation and BluePrint implementation of e-government applications.

Muhamed and Bahuony (2014) stated that the main benefits of IFR (Internet Financial Reporting) are the potential benefit of reducing the cost of production and distribution of financial information as Internet technology supports organizations reaching a much wider range of users of financial information at a relatively lower cost.

Public sector financial disclosure or reporting using the government's website (e-government) is called IFR. IFR is using the capacity and support of the Internet to communicate interactively about financial information (Oyelere et al., 2003). IFR is the distribution of an organization's financial and performance information using Internet technologies. Hiola et al., (2016) stated that publishing financial reports through IFR media could be done in a relatively short time and with broader coverage of users. Hiola (2016) found that the compliance degree of disclosure of financial information on the web (IFR) by local governments in Sulawesi was still relatively low. Verawaty (2016) stated in her research on public sector organizations that Internet technologies provide an opportunity to improve accountability and responsiveness to the needs of its people.

Act No 14, Article 9, paragraph 4, in 2008, obliges the dissemination of public information in a way that is easily accessible by the community, including through e-government. Based on this, local governments should make use of the irwebsites, as an official means to convey public information.

Research in several countries shows one form of accountability and transparency of local governments is done by publishing its financial report on the Internet (Laswadet all, 2005). Some regulations in Indonesia, e.g. Government Regulation (PP) No. 6 in 2008, Government Regulation No. 3 in 2007 and Permendagri No. 7A in 2007, state implicitly the use of electronic media to disclose information to the public.

Research on the accessibility of financial statements is still rare in Indonesia while similar studies in other countries have not produced the same outcomes. Weli (2017) in her research on the implementation of IFR in 
companies stated factors affecting the level of IFR disclosure include company size, type of industry, listing process on a stock market, the company's performance and corporate governance.

Public disclosure law requires the provision of financial information as part of the public information that must be announced periodically through the e-government media facilities. This motivated the authors to research this topic by associating the accessibility of IFR with variables such as the size of local government, income per capita of population, regional spending and ratio of local own revenue.

Local governments with high regional revenue will demonstrate to their stakeholders that the local government is performing well. The tendency to demonstrate the achievement of this high performance is reasonable as a form of public promotion to its people. This is supported by the research conducted by Craven and Marston (1999), who stated that local government with poor performance would limit access to information of the community.

Local governments with high income per capita have a higher demand for accountability, according to Giroux and McLelland (2003) and Ingram (2004). Accountability is in line with the demand for transparency of financial information, which is given to the community through the provision of information by using egovernment.

Regional spending is used to provide basic services to the public through the provision of various facilities and infrastructure. Local governments with high local expenditures tend to show this to the public to show their performance. Disclosure of information to the public is more easily provided through the official e-government facilities of the local government.

The size of a local government is represented by the local population. According to Groff and Pitman (2004), large cities generally have more accounting activities and larger budgets for information technology services. This accounting activity is related to the needs of its citizens, who request more financial information.

This study aimed to analyze whether there is a positive correlation between the ratio of the regional revenue to the size of the local government, and the ratio of regional spending to the local income per capita using the accessibility of IFR. The population in this study are all municipalities in West Java provided their egovernment services were not under repair in April 2018.

\section{Theoretical Background}

\subsection{Literature Review}

With the implementation of Law No. 22 of 1999, which later became Law No. 32 of 2004 on Regional Government and Law No. 25 of 1999 that became Law No. 33 of 2004 on financial balance between central and regional governments, the era of regional autonomy began in Indonesia. These laws separate the functions of the regional governments (executive) and the functions of the people's representatives (legislative). Thus, there is an agency relationship between the local government and the people's representatives. Jensen et al. (1976) described agency relationships as contracts in which one or more persons engage with others to serve those involved with some decision-making authority to the agent.

Signaling theory explains that the government as a party, given the mandate of the people, tries to signal the community (Evans and Patton, 1987) with the goal that the people will continue to support the current government. Financial statements can be used as a means to signal the community. Good governance performance are informed to the people both as a form of responsibility and as a promotion for public purposes.

According to Verawaty (2015), both theories (signaling theory and agency theory) are the basis that public information disclosure is necessary, including through the Internet with e-government facilities. The use of IFR has many advantages: IFR can distribute information quickly (timeliness) and can be used to disclosure financial statements more adequately (disclosure).

\subsection{Hypothesis Development}

\subsubsection{Locally Regional Revenue}

Locally Regional Revenue (LRR) is an important source of income for a region in meeting its spending. Law No. 33 of 2004 defines LRR i as income earned by areas levied according to local regulations by their laws and regulations.

Local governments with high revenue will demonstrate to their stakeholders that they are performing well. Local governments with poor performance will limit access to information of the community (Craven \& Marston, 1999). Conversely, according to signaling theory, local governments with good performance will disclose more information by using better information-delivery techniques. This is also supported by research 
conducted by Ingram (1984) and Laswad et al. (2005) that the greater is a region's wealth, the greater is the level of disclosure made by the local government.

H1. Locally Regional Revenue (LRR) ratio significant and positive influences Internet Financial Reporting (IFR) Index.

\subsubsection{Income Per Capita}

According to Giroux and McLelland (2003) and Ingram (2004), regions with larger income per capita have a higher demand for accountability. High-income areas will have higher political oversight by community groups and will demand more information be disclosed on performance. In today's transparency era, people are aware that they are entitled to public information, including financial information.

The demand for accountability and transparency by populations with high income identifies a positive relationship between local revenue and the provision of financial statements on e-government websites.

H2. The income per capita has a significant and positive influence on IFR Index.

\subsubsection{Regional Spending}

According to Law No. 32 of 2004, regional spending must be used to protect and improve the quality of people's lives in the form of improving basic services, education, provision of health service facilities, social facilities, and public facilities as well as developing a social security system. The higher is the level of service provided, the higher is the desire of a local government to disclose its service information through its website. Regional Spending can be categorized as direct spending or indirect spending. Direct spending is spending directly related to activities, whereas indirect spending is spending that is not directly related to the implementation of activities. Direct expenditure greatly affects the output of activities of a region. Therefore, the higher is the ratio of direct expenditure to total, expenditure is the higher the desire of the local government to disclose the service information through the local government website.

H3. Regional spending has a significant and positive influence on IFR Index.

\subsubsection{Size}

The studies on the IFR of local governments report that there is a relationship between population and IFR. This is also supported by research conducted by Styles and Tennyson (2007) stating that cities with higher populations will provide easier access to financial statement information through the Internet. Therefore, it can be concluded that the greater local populations will have a higher demand for easy accessibility to financial statement information.

H4. Size has a significant and positive influence on IFR Index.

\section{Research Methodology}

\subsection{Data Collection}

The population used in this study includes all district and municipal governments in West Java. The sample was determined based on the criteria that: they utilized e-government in April 2018, and their website was not under repair. Data were also collected through the website of the Central Bureau of Statistics.

\subsection{Operational Definition}

The following model was used in this research and the variables are defined in Table 1.

$$
I F R i t=\alpha i t+\beta 1 i I C i t+\beta 2 i R S i t+\beta 3 i L G R i t+\beta 4 i S I Z E i t++\varepsilon i t
$$

Table 1. Variable Definition

\begin{tabular}{cc}
\hline & Name \\
\hline IC & Income per Capita \\
RS & Regional Spending \\
LRR & Locally Regional Revenue \\
SIZE & Size of City Government \\
\hline
\end{tabular}


According to Styles and Tennyson (2007), the Calculation of Accessibility Index Value (CAVI) is the basis for assessing how many steps are needed to find financial statements in e-government. This index is measured as shown in Table 2.

Table 2. Calculation of Accessibility Index Value (CAVI)

\begin{tabular}{|c|c|c|}
\hline Point & Code & Description \\
\hline+1 point & A & $\begin{array}{l}\text { If the official city website appears on the first page of results for } \\
\text { Google or Yahoo search using city name and state }\end{array}$ \\
\hline+1 point & B & $\begin{array}{l}\text { If the official city website has the link to CAFR data on the } \\
\text { website homepage }\end{array}$ \\
\hline+1 point & $\mathrm{C}$ & $\begin{array}{l}\text { If the official city website has the search engine that finds CAFR } \\
\text { using terms CAFR and financial statement }\end{array}$ \\
\hline+1 point & $\mathrm{D}$ & $\begin{array}{l}\text { If } 3 \text { or fewer web pages (or clicks of the mouse) to view CAFR } \\
\text { data from the city website homepage }\end{array}$ \\
\hline+1 point & $\mathrm{E}$ & $\begin{array}{l}\text { If CAFR provided on the official city website as an indexed pdf } \\
\text { file(s) or HTML format. }\end{array}$ \\
\hline+1 point & $\mathrm{F}$ & $\begin{array}{l}\text { If the city provides CAFR data in more than one file; files for } \\
\text { different sections/pages of full CAFR document }\end{array}$ \\
\hline+1 point & G & $\begin{array}{l}\text { If the individual file(s) providing CAFR data less than } 3 \mathrm{MB} \text { in } \\
\text { size }\end{array}$ \\
\hline+1 point & I & If the official city website provides CAFR data for prior years \\
\hline+1 point & $\mathrm{J}$ & $\begin{array}{l}\text { If the official city website provides information on obtaining or } \\
\text { access to a printed copy of the city's CAFR }(J)\end{array}$ \\
\hline
\end{tabular}

$=$ Possible scores of 10 points.

CAFR = Comprehensive Annual Financial Report

\section{Results and Discussion}

\subsection{Research Population}

The survey conducted on all district and municipal governments in West Java are 27 local governments consisted of 18 regencies and 9 cities. The preliminary survey, as shown in Table 3, indicates that all local governments had e-government in online status.

Table 3. Status of E-Government

\begin{tabular}{|c|c|c|c|c|c|}
\hline No & City/Regencies & $\begin{array}{l}\text { Status of E- } \\
\text { Government }\end{array}$ & No & City/Regencies & $\begin{array}{l}\text { Status of E- } \\
\text { Government }\end{array}$ \\
\hline \multicolumn{3}{|c|}{ Regencies } & 14 & Kab Purwakarta & On Line \\
\hline 1 & Kab Bandung & On Line & 15 & Kab Subang & On Line \\
\hline & Kab Bandung & & 16 & Kab Sukabumi & On Line \\
\hline 2 & Barat & On Line & 17 & Kab Sumedang & On Line \\
\hline 3 & Kab Bekasi & On Line & 18 & Kab Tasikmalaya & On Line \\
\hline 4 & Kab Bogor & On Line & \multicolumn{3}{|c|}{ Cities } \\
\hline 5 & Kab Ciamis & On Line & 19 & Kota Bandung & On Line \\
\hline 6 & Kab Cianjur & On Line & 20 & Kota Banjar & On Line \\
\hline 7 & Kab Cirebon & On Line & 21 & Kota Bekasi & On Line \\
\hline 8 & Kab Garut & On Line & 22 & Kota Bogor & On Line \\
\hline 9 & Kab Indramayu & On Line & 23 & Kota Cimahi & On Line \\
\hline 10 & Kab Karawang & On Line & 24 & Kota Cirebon & On Line \\
\hline 11 & Kab Kuningan & On Line & 25 & Kota Depok & On Line \\
\hline 12 & Kab Majalengka & On Line & 26 & Kota Sukabumi & On Line \\
\hline 13 & Kab Pangandaran & On Line & 27 & Kota Tasikmalaya & On Line \\
\hline
\end{tabular}




\subsection{Result Test}

\subsubsection{Normality Test}

The normality test aimed to test whether independent variables and the dependent variable were normally distributed in the regression model.

Table 4. One-sample Kolmogorov-Smirnov Test

\begin{tabular}{|r|r|}
\hline & \multicolumn{2}{|c|}{$\begin{array}{c}\text { Unstandardized } \\
\text { Residual }\end{array}$} \\
\hline $\mathrm{N}$ & 27 \\
\hline $\begin{array}{r}\text { Normal Parametes } \\
\text { Mean }\end{array}$ & 0,0000 \\
$\begin{array}{r}\text { Std } \\
\text { Deviation }\end{array}$ & 2,71939725 \\
\hline Absolute & 0,158 \\
\hline Positive & 0,158 \\
\hline Negative & $-0,114$ \\
\hline Test Statistic Extreme Differences & 0,158 \\
\hline Asymp.Sig. (2-tailed) & \\
\hline
\end{tabular}

Based on Table 4, the result shows a significant value of 0.096. Asymp value. Sig (two-tailed) shows that the significance value of 0.096 is more than the 0.05 significance level $(0.096>0.05)$; therefore it can be concluded that the data used in this study are normally distributed.

\subsubsection{Autocorrelation Test}

The autocorrelation test aimed to test whether the linear regression model correlates residual in period $\mathrm{t}$ with a residual period t-1 (previous period).

Table 5. Model Summary

\begin{tabular}{|l|c|c|c|c|c|}
\hline $\begin{array}{l}\text { Mod } \\
\text { el }\end{array}$ & R & $\begin{array}{c}\text { Square } \\
\text { S Square }\end{array}$ & $\begin{array}{c}\text { Adjusted } \\
\text { Std. The } \\
\text { error of } \\
\text { The } \\
\text { Estimate }\end{array}$ & $\begin{array}{c}\text { Durbin } \\
- \\
\text { Watson }\end{array}$ \\
\hline 1 & 0.229 & 0.052 & -0.128 & 2,967 & 1.363 \\
\hline
\end{tabular}

According to Table 5, the value obtained from the Durbin-Watson (DW) test is 1.363. The value of DurbinWatson with $\alpha=5 \%$ for $\mathrm{n}=27$ and the independent variable $(\mathrm{k})=4$ are $\mathrm{dl}=1.0616$ and $\mathrm{du}=1.7591$. Since (4$1.363)>1.7591$, it can be concluded that the model does not have an autocorrelation problem.

\subsubsection{Multicollinearity Test}

The multicollinearity test aimed to see whether there is a correlation among the independent variables in the regression model. This test was done using the values of tolerance and Variance Inflation Factor (VIF). A regression model was free of multicollinearity if it possessed a Tolerance value above 0.1 and VIF under 10.

Table 6. Multicollinearity Test

\begin{tabular}{|l|c|c|}
\hline \multirow{2}{*}{ Model } & \multicolumn{2}{|c|}{ Collinearity Statistics } \\
\cline { 2 - 3 } & Tolerance & VIF \\
\hline IC & 0,394 & 2,535 \\
\hline RS & 0,400 & 2,499 \\
\hline LRR & 0,212 & 4,712 \\
\hline SIZE & 0,911 & 1,097 \\
\hline
\end{tabular}


According to the result in Table 6, the tolerance values of the four variables are above 0.1 and VIFs of the four variables are below 10. Therefore, it can be concluded that there are no symptoms of multicollinearity among the independent variables used in the regression model.

\subsubsection{Heteroscedasticity Test}

The heteroscedasticity test aimed to test whether the regression model has inequality residual variance from one observation to another observation. To detect the occurrence of heteroscedasticity, the level of significance of all variables must be greater than 0.05 . In Table 4 , it can be seen that the value of absolute unstandardized residual is 0.158 , which is above the level of significance of $0.05(0.158>0.05)$. Therefore, it can be concluded that the regression model used in this study does not experience symptoms of heteroscedasticity.

\subsection{Hypothesis Test}

The F-value analysis was conducted to determine whether the regression model used in this study is feasible for further analysis. The model is feasible if the significance value $<0.005$. Based on the test result in Table 7 , the level of significant value is 0.000 , which is $<0.005$. Therefore, it can be concluded that the regression model in this study is feasible for further testing analysis.

Table 7. F-Value Analysis

\begin{tabular}{|l|c|c|c|c|c|}
\hline \multicolumn{1}{|c|}{ Model } & $\begin{array}{c}\text { Sum of } \\
\text { Squares }\end{array}$ & df & $\begin{array}{c}\text { Mean } \\
\text { Square }\end{array}$ & F & Sig \\
\hline $\begin{array}{l}\text { Regressi } \\
\text { on }\end{array}$ & 10,237 & 4 & 2,559 & 0,291 & 0,000 \\
\hline Residual & 184,878 & 21 & 8,804 & & \\
\hline Total & 195,115 & 25 & & & \\
\hline
\end{tabular}

The results of all the hypothesis tests are summarized in Table 8.

Table 8. Result Summary

\begin{tabular}{|l|c|c|c|}
\hline \multicolumn{1}{|c|}{ Variable } & Sig & Test & Result \\
\hline IC & 0.541 & $0.541>0.05$ & Reject \\
\hline RS & 0.542 & $0.542>0.05$ & Reject \\
\hline LGR & 0.722 & $0.722>0.05$ & Reject \\
\hline SIZE & 0.856 & $0.856>0.05$ & Reject \\
\hline
\end{tabular}

\section{Hypothesis 1:}

Based on the regression result, the significant value is 0.722 . This value is greater than the value of significance $\alpha=0.05$, thus the ratio of LRR is not a determinant factor to explain the accessibility of IFR through egovernment. In general, local governments with high local revenues will try to maximize services to the community through the provision of various programs and facilities. The provision of these programs and facilities will use a variety of resources, therefore the need to disclose the high level of financial information in its financial statements will be higher. This is also supported by research conducted by Ingram (1984) and Laswad et al. (2005) showing that the greater is the region's wealth, the greater is the level of disclosure made by local governments. However, in reality, the result of this study shows that Bekasi has the highest locally generated revenue, but has the level of IFR of 1 out of the ideal level of 10. On the other hand, Tasikmalaya has the lowest regional revenue ratio among the local governments of West Java, but the value of accessibility of IFR is relatively good with a value of 7 . The city of Depok with the second-highest LRR ratio has an IFR accessibility value of 5, still lower than Tasikmalaya. Meanwhile, local governments with a level of LRR ratios above the average still do not have good IFR, such as Kota Sukabumi and Kota Bekasi with Internet accessibility value of 1 .

\section{Hypothesis 2:}

Based on the regression result, the significant value is 0.541 . This value is greater than the value of significance $\alpha=0.05$, thus the income per capita of a local government is not a determinant factor that can explain the 
accessibility of IFR through e-government. Based on previous literature studies, according to GASB (1999) and GFOA (2003), Styles and Tennyson (2007) stated that regions with larger income per capita have higher accountability demand for financial statements. This was also supported by Verawaty and Merina (2011). However, in reality, the highest income per capita of local government is in the city of Bandung, which has access to IFR with a value of 8 . Bekasi and Purwakarta Regency with the second and third highest income per capita only have access to IFR with a value of 1. Meanwhile, local governments with above-average income per capita values still do not have good Internet accessibility values, such as Sukabumi and Kota Bekasi with Internet accessibility values of 2 and 1 , respectively.

\section{Hypothesis 3:}

Based on the regression result, the significant value is 0,542 . This value is greater than the value of significance, $\alpha=0.05$, thus the ratio of regional spending is not a determinant factor that can explain the accessibility of IFR through e-government. Bekasi's local governments has the highest regional expenditure ratio but has the lowest IFR accessibility of 1 (one). Meanwhile, Kabupaten Tasikmalaya, which has the second-lowest regional spending ratio, has an IFR accessibility value of 7. Furthermore, local governments with above-average spending ratio still do not have good Internet accessibility, such as Kota Sukabumi and Kota Bekasi with Internet accessibility values of 2 and 1, respectively. The only local government with an above-average spending ratio that has a relatively good IFR accessibility value is Cirebon City with a value of 7 .

\section{Hypothesis 4:}

Based on regression results, the significant value is 0.856 . This value is greater than the significance value, $\alpha=$ 0.05 , thus the size of a local government is not a determinant factor that can explain the accessibility of IFR. Bogor Regency is the local government with the largest local government size and has a IFR value of 7 . However, this value is still not the ideal value of 10. This is followed by Bandung Regency, the second-largest local government, which also has IFR accessibility value of 7. Meanwhile, Bekasi and Kota Bekasi, with the third- and fourth-largest local governments, have the smallest Internet accessibility of 1.

\section{Conclusion}

The law of public disclosure requires the provision of financial information as part of the public information that must be published periodically through e-government. This study analyzed the accessibility of financial statements through e-government by linking with variables such as the size of local government, income per capita, regional spending and regional revenue ratio. The result of this research is that there is no positive correlation of local government size, income per capita of population, regional spending or regional revenue ratio with the accessibility of IFR.

The study has many limitations, thus the authors here provide suggestions for further research as follows: increase the number of samples as the analysis results of this study cannot be generalized to all local governments in Indonesia; and add other variables that could further explain the accessibility of IFR to widen the benefits of this research.

\section{References}

Craven, B. M., \& Marston, C. L. (1999). Financial reporting on the Internet by leading UK companies. European Accounting Review, 8(2), 321-333. doi: 10.1080/096381899336069.

del Carmen, M., Pedro, M., \& Lopez, A. (2014). The determinants of government financial reports online. Transylvanian Review of Administrative Sciences, 42e, 5-31

Giroux, G., \& McLelland, A. J. (2003). Governance structures and accounting at large municipalities. Journal of Accounting and Public Policy, 22(3), 203-230. doi: 10.1016/S0278-4254(03)00020-6.

Groff, J. F., \& Pitman, M. K. (2004). Municipal Financial Reporting on the World Wide Web: A survey of Financial Data Displayed on the Official websites of the 100 largest US Municipalities. Journal of Government Financial Management, 53(2), 20-30.

Hola, Yustina, R., Dedi, M., \& Aji. Political environment in the effect of regional government financial performance on disclosure of financial information on website. Journal of Economics, Business and Accountancy Ventura, 19(1, April-July), 27-36.

Iii, J. H. E., \& Patton, J. M. (1987). Signaling and monitoring in public sector accounting. Journal of Accounting Research, 25 (Suppl.), 130-158. doi: 10.2307/2491083. 
Ingram, R. W., \& Dejong, D. V. (1987). The Effect of regulation on Local Government disclosure practises. Journal of Accounting and Public Policy, 6(4), 245-270. doi: 10.1016/S0278-4254(87)80002-9.

Instruksi Presiden Nomor 3 Tahun 2003. Kebijakan dan Strategi Nasional Pengembangan E-Government. Instruksi Presiden Nomor 6 Tahun 2001. Telematika (Telekomunikasi, Media dan Informatika).

Jensen, M. C., \& Meckling, W. H., W.1976.Theory of the Firm (1976) Theory of the firm: Managerial behavior, agency costs and ownership structure. Journal of Financial Economics, 3(4), 305-360. doi: 10.1016/0304-405X(76)90026-X.

Laswad, F., Fisher, R., \& Oyelere, P. (2005). Determinants of voluntary Internet financial reporting by Local Government authorities. Journal of Accounting and Public Policy, 24(2), 101-121. doi: 10.1016/j.jaccpubpol.2004.12.006.

Mohamed, K. A. (2014). Ehab, and Basuony AK, Mohamed. Determinants and characteristics of voluntary Internet disclosure in GCC countries. International Journal of Digital Accounting Research, 14, 57-91

Oyelere, P., Laswad, F., \& Fisher, R. (2003). The determinant of Internet Financial Reporting by New Zealand Companies. Journal of International Financial Management and Accounting, 14, 1-25.

Peraturan Pemerintah Nomor 3 Tahun 2007. Laporan penyelenggaraan pemerintahan daerah kepada pemerintah, laporan keterangan pertanggungjawaban kepala daerah kepada dewan perwakilan daerah,dan informasi laporan penyelenggaraan pemerintahan daerah kepada masyarakat.

Peraturan PemerintahNomor 7A Tahun2007. Tata cara penyampaian informasi dan tanggapan atau saran dari masyarakat atas laporan penyelenggaraan pemerintahan daerah.

PeraturanPemerintahNomor 6 Tahun 2008. Pedoman evaluasi penyelenggaraan pemerintahan daerah kepada masyarakat.

Republik Indonesia. Undang-UndangNomor14 Tahun 2008. Keterbukaan Informasi Publik.

Styles, A. K., \& Tennyson, M. (2007). The accessibility of financial reporting of US municipalities on the Internet. Journal of Public Budgeting, Accounting and Financial Management, 19(1), 56-92. doi: 10.1108/JPBAFM-19-01-2007-B003.

Verawaty (2015). Determinan aksesibilitas Internet Financial Reporting melalui E-government Pemerintah Daerah di Indonesia. Medan, Indonesia: SNA

Verawaty, V. (2016). The comparative analysis of accessibility index value of government Internet financial reporting in Indonesia. Applied Finance and Accounting, 2(2). doi: 10.11114/afa.v2i2.1214

Weli, W. The company's internal characteristics and mandatory disclosure size of web-based financial reporting. Journal of Economics, Business and Accountancy Ventura, 19(3, March), 435-446. doi: 10.14414/jebav.v19i3.627 